\title{
CRYSTAL FORMATION IN CULTURES OF FUNGI : NEW RECORDS FROM BANGLADESH
}

\author{
SHAMIM SHAMSI ${ }^{1}$, NAJMUN NAHER ${ }^{2}$ AND YASMIN FATEMA \\ Department of Botany, University of Dhaka, Dhaka-1000, Bangladesh \\ ${ }^{2}$ Department of Botany, Life and Earth Science Group, National University, \\ Gazipur-1704, Bangladesh.
}

\begin{abstract}
In the present study crystal formations were detected in the culture of Aspergillus niger, A. fluvus, Aspergillus sp., Bipolaris sorokiniana, Cladosporium spp., Colletotrichum gloeosporioides, Colletotrichum orbiculare,Curvularia spp., Fusarium sp., Paecilomyces spp., Penicillium sp., Pestalotia sp., Pestalotiopsis guepinii, Phaeoisariopsis personata, Trichoderma viride and seven sterile culture of fungi. Eighteen types of crystallographic structures were detected from different fungal isolates. This is the first report of formation of crystal in fungal cultures from Bangladesh.
\end{abstract}

Key words: Crystal, Culture, Fungi, Bangladesh

\section{Introduction}

Occurrence of crystals was considered as a rarity in the world of fungi because their existence was, at that time (1880), known only in the Phycomycetes studied first by Klein (1872) and later by Van Tieghem (1878). Zopf (1890) referred to the work of Van Tieghem (1878) who found crystals in cultures of quite a number of Fungi Imperfecti. Production of crystals by fungi has also been reported by de Bary (1887).

Despite the identical chemical composition of the crystals, their crystallographic form shows the greatest variability (Borzani 1959). In the language of crystallographer crystal may be acicular (very slender forms), capillary, radiated, satellite, columnar, rosette and many other form. Previously, crystals had been recorded in Dermatophytes namely, Keratinomyces ajelloi (4 strains), Microsporon, n. sp. Microsporon audouinii (the genus Microsporon is synonym of Mycosporum), Epidermophyton floccosum, Mixotrichum conjugatum and Rozites gonglyophora. In Hyphomycetes, Aspergillus fumigatus and A. fluvus produced crystal (Benedek 1961, Borzani 1959, 1960 and Borzani et al. 1960).

Lot of researches had been carried out on crystals in fungal culture and its chemical composition (Graustain et al. 1977, Punja and Jenkins 1984, Smith et al. 1986 and Arnott 1995). Recently different types of crystals were observed in sporulating fungal culture. Since there is no report on this regards in Bangladesh, the present investigation

\footnotetext{
${ }^{1}$ Corresponding author: E-mail: prof.shamsi@gmail.com
} 
was undertaken to record the different types of crystal forms as they occur in fungal cultures.

\section{Materials and Methods}

The fungi were isolated from healthy and diseased plant parts following "Tissue planting" and "Blotter" methods (Tuite 1969). Some air borne fungi isolated on Potato Dextrose Agar (PDA) plate were found to produce crystals in cultures at $25-28{ }^{\circ} \mathrm{C}$ and $\mathrm{pH} 6$, within 7 days of incubation. Sporulating fungal cultures showed crystal in slide. Fungal structure like mycelia, spore bearing structures and spores were scrapped off from the surface of the sporulating colony with a scalpel or blade or picked up with a needle and was mounted in lacto phenol over a clean slide for microscopic observation. In case of hyaline structures, a little amount of aniline blue (cotton blue) was added to the mounted fluid. Crystals may be found as early as the seventh day and older culture contain more crystals.

Crystals ware observed with fungal structures under Binocular microscope with normal light. Under microscopic view different types of crystals were observed in different fungal species. The isolated fungi were identified based on morphological characteristics observed under a compound microscope following standard keys (Barnett and Hunter 2000, Booth 1971, Ellis 1971, 1976, Ellis and Ellis 1997 and Sutton 1980).

\section{Results and Discussion}

The diverse crystallographic structures found in the cultures of Deuteromycetous fungi were isolated during July 2009 to May 2014. In total 20 species of fungi belonging 11 genera of Deuteromycetes and seven sterile fungi were found to produce crystals in cultures (Table 1). The different strains of the same species of the fungi may produce the different crystallographic forms (Plates 1 to 3 ). On the other hand, the same crystallographic forms may occur in cultures of different, unrelated species of fungi (Table 1). The crystal forms may be entirely different in the same species (Table 1 and Plate 4). English and Jensen (1958) mentioned that crystals are the flowers of mineral kingdom.

In the present study crystal formations were detected in the culture of Aspergillus flavus Link., A. niger Van Tiegh., Aspergillus sp., Bipolaris sorokiniana (Sacc.) Shoem,, Cladosporium spp. Colletotrichum gloeosporioides (Penz.) Penz. and Sacc., Colletotrichum orbiculare, Curvularia spp., Fusarium spp., Penicillium sp., Pestalotia sp., Pestalotiopsis guepinii (Desm.) Stayaert, Phaeoisariopsis personata (Berk and M.A. Curtis) Arx., Paecilomyces sp., Trichoderma viride Pers. and seven sterile fungi. 
Crystal formation in cultures

Table 1. Different crystallographic types associated with different fungi isolated from different hosts/ habitats.

\begin{tabular}{|c|c|c|}
\hline Name of Fungi & Crystal Type & Host/Habitat \\
\hline Aspergillus niger & Radiated & On air \\
\hline Apergillus fluvus & Oval & On air \\
\hline Aspergillus sp. & Columnar, Quadrilateral transparent & On air \\
\hline Bipolaris sorokiniana & Acicular branched & Triticum aestivum \\
\hline Cladosporium $\mathrm{sp}_{1}$ & Rosette- stellate, spindle shape stellate & On air \\
\hline Cladosporium $\mathrm{sp}_{2}$. & Radiated, Rosette- stellate, irregular & On air \\
\hline Cladosporium $\mathrm{sp}_{3}$. & Triangular & On air \\
\hline Colletotrichum gloeosporioides & Radiated-stellate & Datura metel \\
\hline Colletotrichum orbiculare. & 'Fish-tail' & Gerbera sp. \\
\hline Curvularia $\mathrm{sp}_{1 .}$ & Triangular, Rosette & Oryza sativa \\
\hline Curvularia $\mathrm{sp}_{2}$. & Columner & $\begin{array}{l}\text { Houttuynia } \\
\text { cordata }\end{array}$ \\
\hline Fusarium $\mathrm{sp}_{1}$. & Granular & On air \\
\hline Fusarium $\mathrm{sp}_{2}$. & 'Fish-tail' & $\begin{array}{l}\text { Solanum } \\
\text { melongena }\end{array}$ \\
\hline Paecilomyces sp. & Bar, spindle shape stellate & On air \\
\hline Penicillium sp. & Columnar & Citrus sinensis \\
\hline Pestalotiopsis guepinii & Rosette- stellate & $\begin{array}{l}\text { Houttuynia } \\
\text { cordata }\end{array}$ \\
\hline Pesatalotia sp. & Rosette- stellate, Quadrilateral stettate & On air \\
\hline Phaeoisariopsis personata. & Rosette- stellate & Arachis hypogaea \\
\hline Rhizopus sp. & Radiated-stellate & On air \\
\hline Trichoderma viride. & 'Fish-tail' & On air \\
\hline Sterile fungi & $\begin{array}{l}\text { Acicular, Columnar, Granular, Rosette- } \\
\text { stelleate, Quadrilateral, Quadrilateral } \\
\text { stellate, }\end{array}$ & $\begin{array}{l}\text { Datura metel, on } \\
\text { air }\end{array}$ \\
\hline
\end{tabular}

Eighteen different types of crystallographic structures were recorded and classified in this study. The types were Oval, Radiated, Radiated- stellate, Rosette, Rosette- stallate, Colamnar, Granular, Bar, Spindle, Spindle-stellate, Quadrilateral stellate, Quadrilateral, Triangular, Quadrilateral transparent, Irregular, Acicular, Acicular branched and Fishtail. Present observation supports the results of Benedek (1961 and 1962). In earlier studies crystals were reported to form in fungi grown in malt extract. In the present study all the crystal types formed on PDA medium at the temperature 25 to $28^{\circ} \mathrm{C}$ and $\mathrm{pH} 6.0$.

Oval, Acicular branched, Quadrilateral transparent, Granular, Quadrilateral stellate and Triangular shaped of crystals were not reported earlier, thus this is the first report of these six morphological types of crystals. Previously crystals had been reported in cultures of Aspergillus flavus, A. fumigatus, Penicillium sp, Curvularia sp. and Fusarium sp. No report is available on the presence of crystals in cultures of Aspergillus niger, Aspergillus sp., Bipolaris sorokiniana, Cladosporium spp., Colletotrichum gloeosporioides, Colletotrichum orbiculare, Pestalotia sp., Pestalotiopsis guepinii, Paeciliomyces sp.,Phaeoisariopsis personata, Trichoderma viride and seven sterile fungi. Thus the results obtained from the present investigation indicates that 


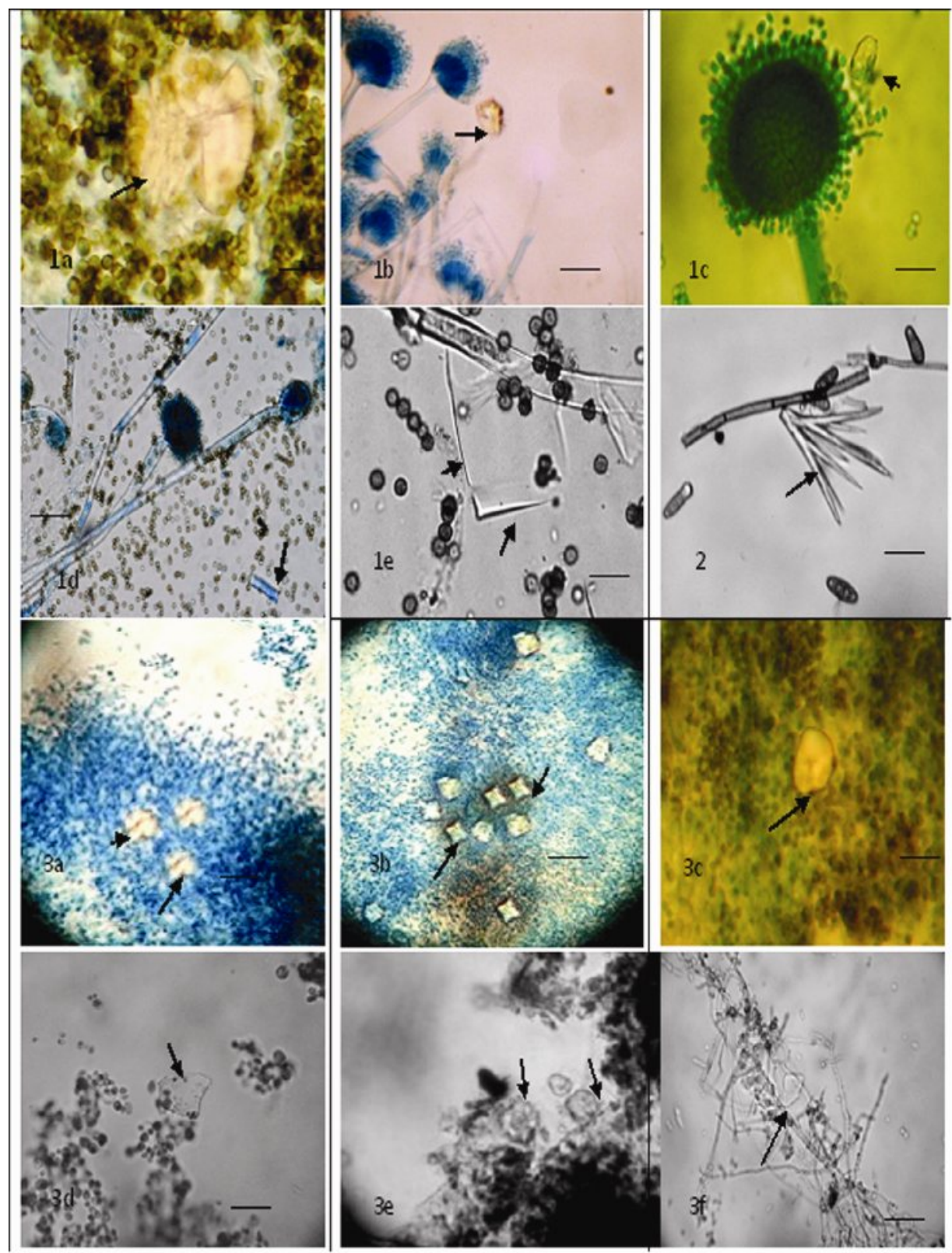

Plate 1. Formation of crystals in culture of fungi: 1. Aspergillus niger. 1b-c. Aspergillus fluvus. 1d. Aspergillus sp. 2. Bipolaris sorokiniana. 3a-b. Cladosporium $\mathrm{sp}_{1 .} 3 \mathrm{c}-\mathrm{e}$. Cladosporium $\mathrm{sp}_{2}$. and Cladosporium $\mathrm{sp}_{3}$. $(\mathrm{Bar}=50 \mu \mathrm{m})$. 


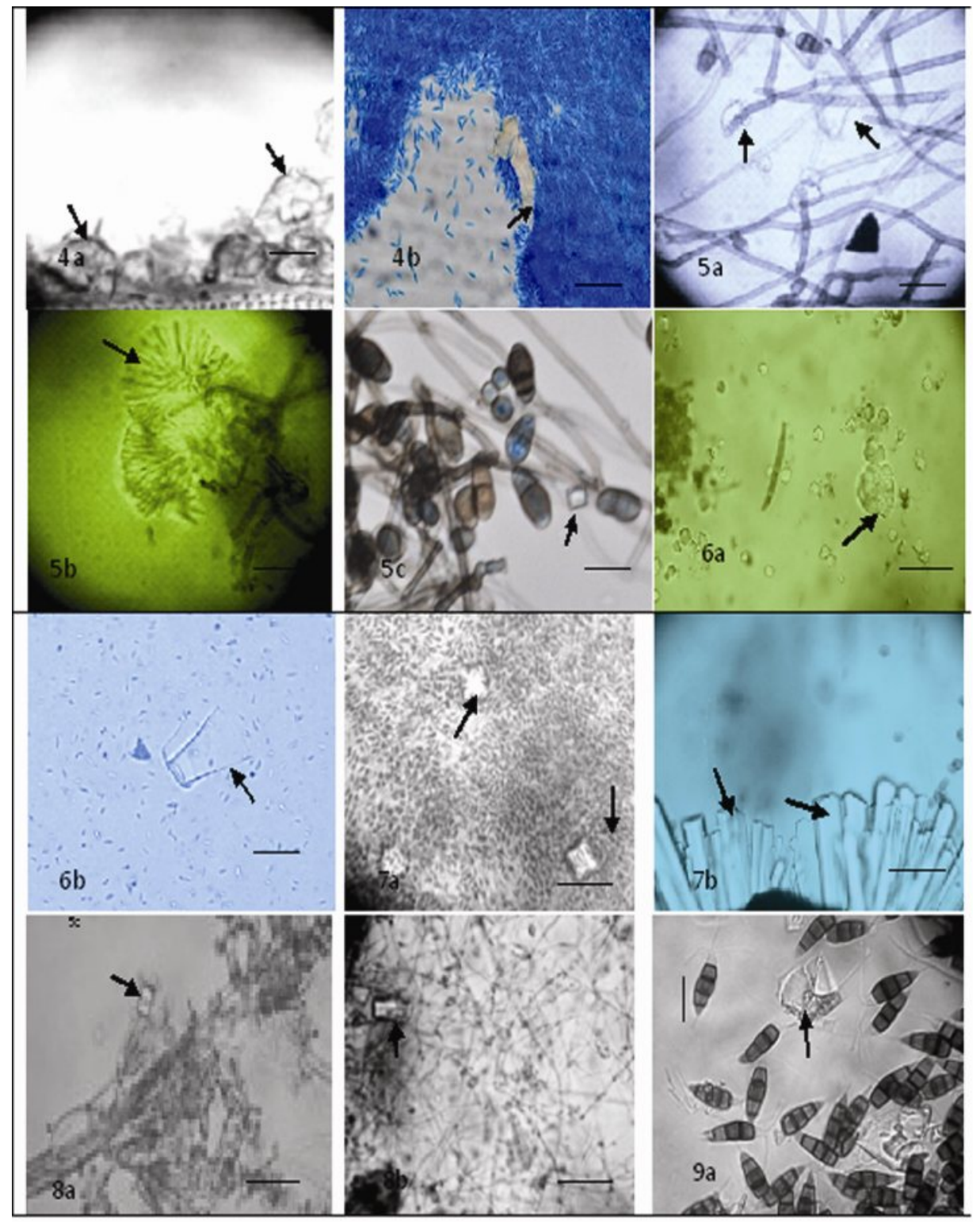

Plate 2. Formation of crystal in culture of fungi: 4a. Colletotrichum gloeosporioides . 4b. Colletotrichum orbiculare. 5a-b. Curvularia $\mathrm{sp}_{1} .5 \mathrm{c}$. Curvularia $\mathrm{sp}_{2}$. 6 a. Fusarium $\mathrm{sp}_{1}$. 6b. Fusarium $\mathrm{sp}_{2}$. 7a-b. Paecilomyces sp. 8a-b. Penicillium sp. 9a. . Pestalotiopsis guepinii (Bars $=50 \mu \mathrm{m}$ and $100 \mu \mathrm{m}[9 \mathrm{a}])$. 


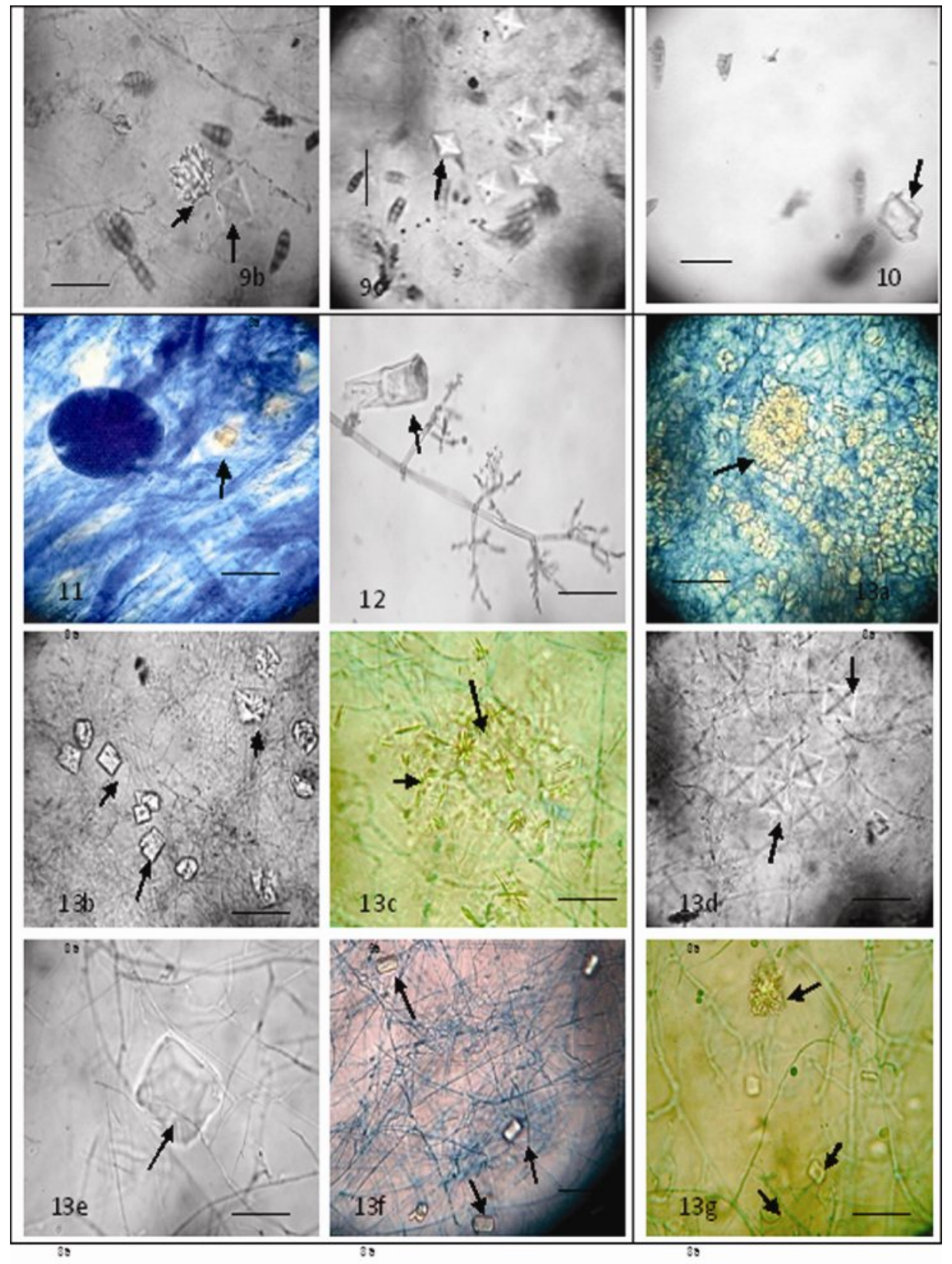

Plate 3. Formation of crystal in culture of fungi: 9b-c. Pesatalotia $\mathrm{sp}_{1}$. 10. Phaeoisariopsis personata. 11. Rhizopus sp. 12. Trichoderma viride. 13a-g. Sterile fungi $(\mathrm{Bar}=50 \mu \mathrm{m})$. 


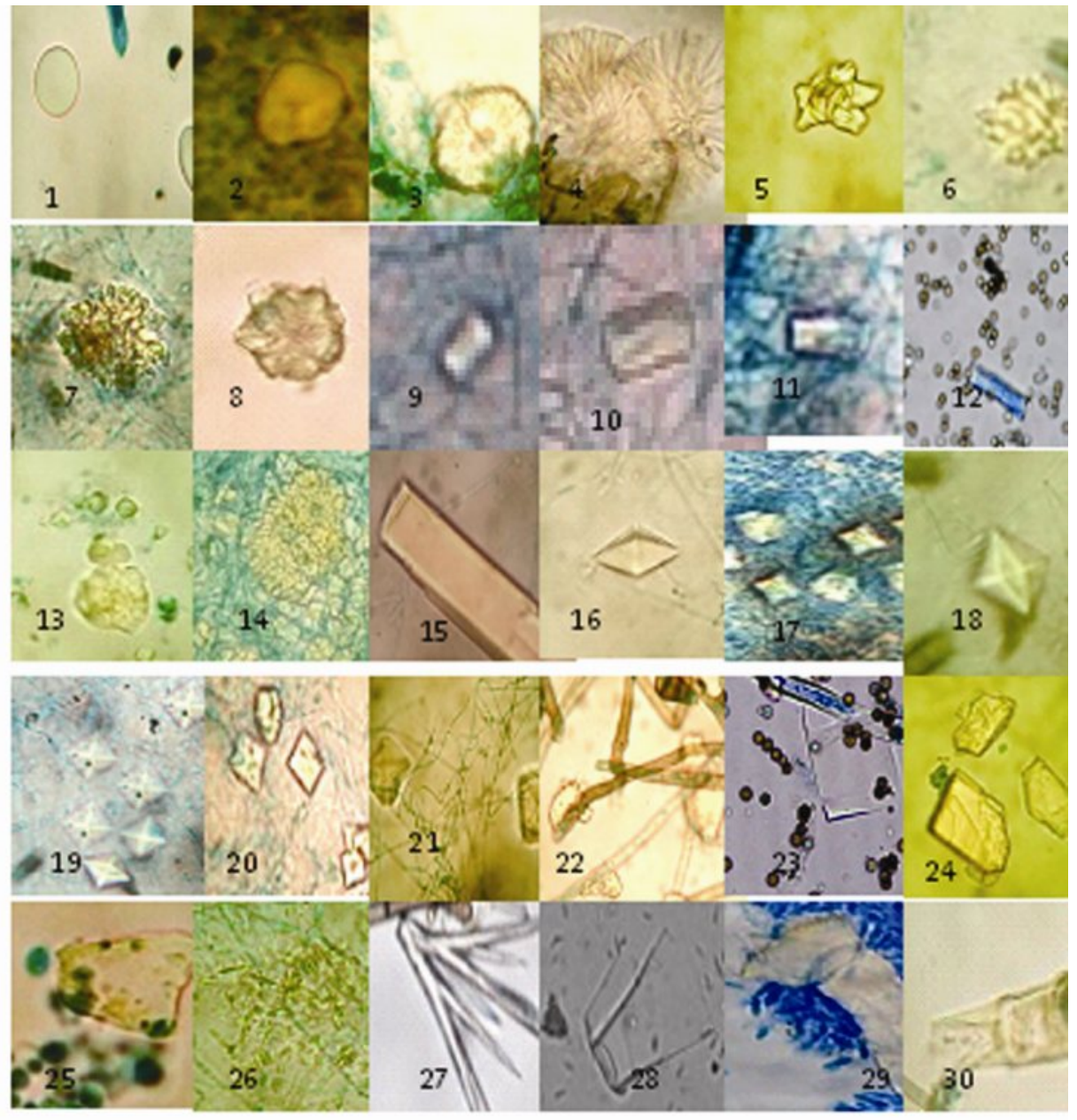

Plate 4. Different shapes of crystal: (1) Oval, (2) Radiated; Radiated-stellate (3) Rosette (4) Rosette- stellate $(5,6,7,8)$ Columnar $(9,10,11,12)$ Granular $(13,14)$, Bar (15) Spindle shape ( 16) Spindle stellate (17) Quadrilateral stellate ( 18-19) Quadrilateral $(20,21)$ Triangular (22) Quadrilateral transparent (23) Irregular (24, 25) Acicular (26) Acicular branched (27) 'Fish-tail'(28 - 30).

formation of crystals in the above mentioned genera are new record. After Benedek (1961 and 1962) no research report is available on crystal shapes found in fungal cultures. Mostly research had been carried out on chemical properties of crystals obtained from fungal cultures (Gadd 1999, Jarosz-Wilkolazka, and Gadd 2003 and Verrecchia et al. 1993). In Bangladesh contest present findings are new addition in Mycological Research. 


\section{References}

Arnott, H. J. 1995. Calcium oxalate in fungi. In: Khan, S. R., editor. Calcium oxalate in Biological systems. Boca Raton.CRP Press. pp.73-111.

Barnett, H. L. and B. B. Hunter. 2000. Illustrated Genera of Imperfect Fungi. (4th edn.), Burgessbub. Co. Minneapolis. pp.218.

Benedek, T. 1961. Crystal formation in culture of fungi: Dermatophytes and other Hyphomycetes . Mycopath. et Mycol. Appl. X14(4): 277-283.

Benedek, T. 1962. Crystal formation in culture of fungi: Apeareance of crystals in white light. Mycopath. et Mycol . Appl. X IV:264- 268+ VI. Mycopath. et Mycol . Appl. X14.

Booth, C. 1971. The Genus Fusarium. The Commonwealth Mycological Institute. England. pp.273.

Borzani, W. 1959. Production of crystals by Rozites ganglyophora. Mycopathologia II. 22.IX.

Borzani, W. 1960. Production of crystals in cultures of Rozites ganglyophora. Mycopath . et Mycol. Appl.XII. 97-100.

Borzani, W., L.R. Marina, Vario, V. Beatriz and B. Pozzi. 1960. Production of crystals in cultures of Rozites ganglyophora: Some properties of thr crystals, influence of the emperature and of the culture medium on the production of crystals. Mycopath. et Mycol. 6.XII . 273-276.

de Bary, A. 1887. Comparative Morphology and Biology of Fungi. Mycetozoa and Bacteria. Clarenden, Oxford. pp. 558

Ellis, M. B. 1971. Dematiaceous Hyphomycetes. The Commonwealth Mycological Institute, England, pp. 608.

Ellis, M. B. 1976. More Dematiaceous Hyphomycetes. The Commonwealth Mycological Institute, England, pp. 507.

Ellis, M. B. and J. P. Ellis. 1997. Micro fungi on Landplants. An Identification Handbook. pp. 868.

English, G.L. and D.E. Jensen. 1958. Getting acquainted with minerals. McGrew Hill Book. Com. NY. pp. 362.

Gadd, G.M., 1999. Fungal production of citric and oxalic acid: importance in metal speciation, physiology and biogeochemical processes. Advances in Microbial Physiology. 41: 47 92.

Graustain, W. C., K.. Cromack and P. Sollins 1977. Calcium oxalate. Occurrence ins soils and effect on nutrient and geochemical cycles. Science. 198:1253-1254.

Jarosz-Wilkolazka, A., Gadd, G. 2003. Oxalate production by wood-rotting fungi growing in toxic metal-amended medium. Chemosphere. 52: 541- 547.

Klein, J. 1872. Zur Kenntniss des Pilobolus. Jahrbücher für wissenschaftliche Botanik. 8:305-381.

Punja, Z.K. and F.S. Jenkins. 1984. Light and scanning electron microscope observations of calcium oxalates produced during growth of Sclerotium rolfsii in culture and in infected tissue. Can. J. Bot . 62:2028-2032.

Smith, V. L., Z.K. Punja and S. F. Jenkins. 1986. A histopathological study of infection of host tissue by Sclerotium rolfsii. Phytopathology. 76:755-759.

Sutton, B.C. 1980. The Coelomycetes, Fungi Imperfecti with Pycnidia Acervuli and Stromata. Commonwealth. Mycological Institute. England. pp. 525-537.

Tuite, J. 1969. Plant Pathological methods. Fungi and Bacteria. Burgess Publishing Company. Minneapolis, Minnesota. USA. pp. 239.

Van Tieghem, Ph. (1878). Nouvelles recherchés sur les Mucorindes, Ann. sc. nat. ser. VI. 1: 2432.

Verrecchia, E.P., J.-L.Dumont and K.E.Verrecchia, 1993. Role of calcium oxalate biomineralization by fungi in the formation of calcretes; a case study from Naza-reth, Israel. J. of Sedimentary Res. 63: 1000- 1006.

Zoff, W. 1890. Die Pilze. Vering von E. Trewendt, Breslau. 47:383 